\title{
EFEK ANTI-ANGIOGENESIS EKSTRAK KAYU SECANG SEBAGAI TERAPI ADJUVANT PADA DIABETES RETINOPATI
}

\author{
Article Review \\ Isma Fadlilatus Sa'diyah ${ }^{1}$, Fitria Putridewi Abidin', Lidya Angelina Purba ${ }^{1}$, Hanifa Yuniasari ${ }^{1}$ \\ ${ }^{1}$ Fakultas Kedokteran, Universitas Lampung
}

Email : ismafs82@gmail.com

\begin{abstract}
ABSTRAK
Diabetes melitus merupakan kelompok penyakit metabolik yang ditandai oleh adanya peningkatan glukosa darah (hiperglikemi) akibat kegagalan tubuh dalam memproduksi insulin, kerja insulin yang tidak adekuat, atau keduanya. Hiperglikemi berkepanjangan pada diabetes kronik dapat menyebabkan kerusakan pada organ-organ penting seperti mata, ginjal, saraf, jantung, dan pembuluh darah. Kerurasakan organ yang paling sering terjadi adalah kebutaan mata pada pasien diabetes retinopati. Mekanisme terjadinya Diabetes Retinopati diduga sebagai akibat dari rangkaian proses inflamasi dan angiogenesis. Kayu Secang (Caesalpinea sappan) memiliki kandungan senyawa polifenol golongan flavonoid yang diketahui dapat menghambat terjadinya proses angiogenis. Proses angiogenesis diblok oleh inhibitor COX-2 yang diinduksi bFGF. COX2 berperan pada proses angiogenesis melalui sintesis prostaglandin (PG). Prostaglandin berperan penting di dalam induksi VEGF. Penghambatan aktivitas COX-2 akan berakibat pada penghambatan angiogenesis. Oleh karena itu, efek antiangiogenesis pada ekstrak Kayu Secang dapat digunakan sebagai terapi adjuvant pasien diabetes retinopati.
\end{abstract}

Kata kunci : Anti-angiogenesis, kayu secang, diabetes retinopati.

\begin{abstract}
Diabetes mellitus is a group of metabolic diseases characterized by an increase in blood glucose (byperglycemia) due to the body's failure to produce insulin, inadequate insulin work, or both. Prolonged byperglycemia in chronic diabetes can cause damage to important organs such as the eyes, kidneys, nerves, heart and blood vessels. The most frequent organ damage is eye blindness in diabetic retinopathy patients. The occurrence mechanism of Diabetes Retinopathy is a result from inflammatory processes and angiogenesis. Secang wood (Caesalpinea sappan) contains a flavonoid polyphenol compound which is known to inbibit the occurrence of an angiogenis process. The angiogenesis process is blocked by COX-2 inhibitors induced by bFGF. COX-2 plays a role in the process of angiogenesis through the synthesis of prostaglandin (PG). Prostaglandin plays an important role in VEGF induction. Inbibition of COX-2 activity will result in inbibition of angiogenesis. Therefore, the anti-angiogenesis effect in Secang Wood extract can be used as an adjuvant therapy for diabetic retinopathy patients.
\end{abstract}

Keywords: antu-angiogenesis, Secang wood, retinophaty diabetes. 


\section{PENDAHULUAN}

Diabetes mellitus (DM) merupakan salah satu penyakit tertua yang diketahui manusia. Diabetes mellitus pertama kali dilaporkan dalam sebuah naskah di Mesir sekitar 3000 tahun yang lalu. Pada tahun 1936, perbedaan antara DM tipe 1 dan DM tipe 2 telah dapat dijelaskan dengan baik. DM Tipe 2 adalah bentuk DM yang paling umum ditandai dengan hiperglikemia, resistensi insulin, dan defisiensi insulin relatif (Olokoba AB, Obateru OA, 2012).

Prevalensi global diabetes mellitus diperkirakan akan meningkat secara signifikan dalam beberapa dekade mendatang, dari sekitar 382 juta pada 2013 menjadi 592 juta pada 2035. Diabetes tipe 2 (T2D) secara khusus telah mencapai tingkat epidemi, sedangkan diabetes tipe 1 (T1D) mengalami peningkatan kejadian secara signifikan (Duh, Sun, et all, 2017).

Gejala klasik diabetes mellitus berupa poliuria, polidipsia, dan polifagia. Selain itu, dapat pula terjadi kehilangan berat badan berat yang biasanya terjadi pada diabetes tipe 1 atau diabetes tipe 2 yang tidak terdeteksi dalam jangka waktu panjang. Mudah lelah dan merasa gelisah juga merupakan gejala yang tidak khas pada orang dengan diabetes mellitus sehingga sulit untuk digunakan dalam mengenali adanya penyakit diabetes mellitus. Adapun gejala khusus yang harus diperhatikan karena dianggap sebagai warning sign yaitu: penurunan berat badan tanpa sebab, sering kelelahan, sensitif, mulut kering, rasa terbakar dan nyeri hingga mati rasa pada kaki, penurunan penglihatan, impotensi atau disfungsi ereksi, mengalami infeksi berulang terutama di daerah genital, saluran kemih, mulut, dan kulit yang sukar sembuh (Ramachandran $\underline{A}, 2014)$.

Pada penderita diabetes mellitus yang tidak dikontrol dengan baik akan menimbulkan berbagai macam komplikasi, baik secara akut maupun kronik. Komplikasi akut diabetes mellitus yaitu dehidrasi/ hipovolemia, gangguan elektrolit, ketoasidosis, gangguan reaksi imun, gangguan proses penyembuhan luka, dan hiperlipidemia. Sedangkan komplikasi kronik terdiri atas komplikasi pembuluh darah besar (makrovaskuler) dan komplikasi pembuluh darah kecil (mikrovaskuler). Kelompok komplikasi makrovaskular adalah penyakit jantung koroner, penyakit pembuluh darah otak, dan penyakit pembuluh darah perifer. Sedangkan kelompok komplikasi mikrovaskuler adalah retinopati, nefropati, dan neuropati. Semakin lama durasi penyakit diderita, maka semakin luas dan berat komplikasi yang dirasakan oleh penderita diabetes mellitus (Lathifah NL, 2017).

Di Indonesia komplikasi terbesar dari diabetes melitus adalah neuropati, kemudian diikuti retinopati. Retinopati merupakan ancaman bagi penderita diabetes karena dapat menyebabkan kebutaan. Berikut gambaran komplikasi diabetes mellitus, termasuk retinopati (Kementrian Kesehatan RI, 2014).

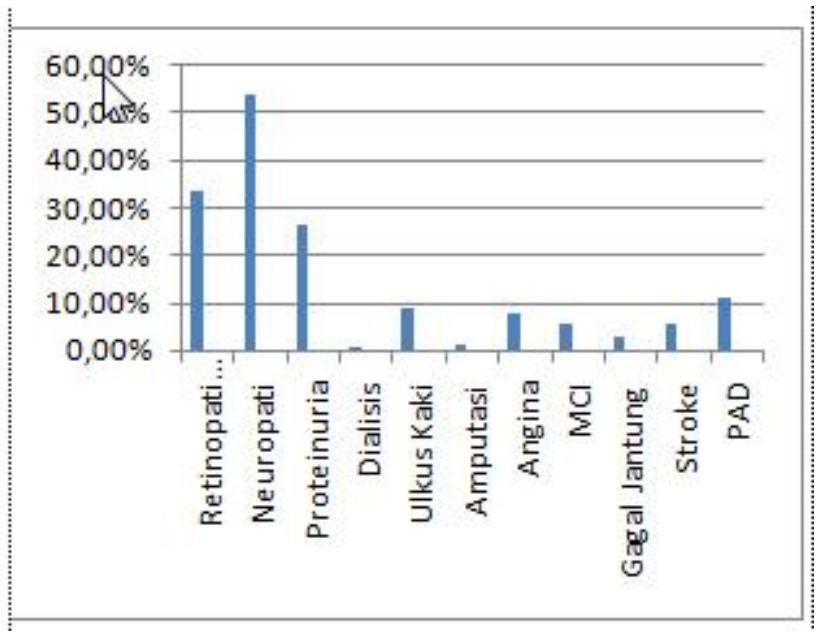

Tabel 1. Presentasi Komplikasi Diabetes Melitus di RSCM tahun 2011 (Kementrian Kesehatan RI, 2014).

Keterangan :

MCI : Mild Cognit

ive Impairment

PAD : Pheriperal Arterial Disease

Pasien diabetes menunjukkan peningkatan kebutaan 25 kali lipat dibandingkan dengan subjek non-diabetes. Lebih lanjut, Diabetes Retinopati adalah penyebab kebutaan paling umum di atas 50 tahun. Prevalensinya meningkat seiring dengan durasi penyakit, mempengaruhi lebih dari 60\% pasien DM tipe 2 yang menderita penyakit ini selama lebih dari 20 tahun. Mekanisme terjadinya Diabetes Retinopati diduga sebagai akibat dari rangkaian proses inflamasi dan angiogenesis. Di tempat terjadinya inflamasi, sel-sel inflamasi dapat 
menghasilkan sitokin angiogenis, faktor pertumbuhan dan protease yang berkontribusi pada pembentukan pembuluh darah baru dan kerusakan jaringan. Neovaskularisasi dan inflamasi menghasilkan sejumlah mediator inflamasi dan jalur pensinyalan seperti jalur COX / prostaglandin. Prostanoid yang dihasilkan oleh COX-2 dapat menginduksi ekspresi VEGF dan faktor proangiogenis lainnya. Dengan demikian, penghambatan COX mengurangi produksi VEGF dan neovaskularisasi retina. Sitokin pro-inflamasi dapat secara langsung menginduksi pembentukan pembuluh melalui keterlibatan sel target endotel atau, secara tidak langsung, dengan menginduksi leukosit dan atau sel endotel untuk menghasilkan mediator proangiogenis. Dalam degenerasi aktivasi kapiler retina, sel inflamasi dan elemen glial juga terlibat. VEGF memicu terjadinya angiogenesis patologis dan meningkatkan permeabilitas pembuluh darah. Selain itu, juga terlibat dalam peningkatan jalur inflamasi melalui induksi sitokin pro-inflamasi lainnya. Dengan demikian, dapat dikatakan bahwa angiogenesis dan proses inflamasi saling terkait dalam mengakibatkan diabetes retinopati (DR). Dapat diprediksi bahwa inflamasi tidak hanya terlibat pada tahap awal DR, tetapi juga pada DR lanjut, dengan neovaskularisasi dan edema (Capitao M dan Soares R, 2016).

\section{Manifestasi Klinis pada Diabetes Retinopati}

Perubahan khas yang terlihat pada retinopati diabetik awal (non-Proliferatif Diabetes Retinopati) adalah mikroaneurisma, perdarahan retina, dan eksudat. Pada awalnya, perubahan ini sering ditemukan sedikit temporal ke daerah pusat makula. Ini disebabkan oleh gangguan integritas vaskular dan hilangnya pericytes. Dalam perjalanan penyakit selanjutnya, kelainan mikrovaskular intraretinal dapat berkembang, berupa dilatasi dan oleh karena itu selama funduskopi terlihat kapiler retina, dan menunjukkan kemungkinan risiko neovaskularisasi dan retinopati diabetik proliferatif. Retinopati diabetik proliferatif disebabkan oleh peningkatan kadar VEGF intraokular akibat iskemia retina karena oklusi kapiler pembuluh retina. Proliferasi dapat tumbuh pada diskus optikus (neovaskularisasi pada diskus) atau di tempat lain di retina (neovaskularisasi di tempat lain) ke dalam vitreous. Pembuluh yang baru terbentuk ini dapat terjadi kebocoran pada angiografi fluoresens dan dapat menyebabkan perdarahan vitreous dan akhirnya retinal detasemen traktual. Pelepasan retina traktional menghasilkan pemisahan retina neurosensori dari epitel pigmen retina. Bagian retina yang terlepas menyebabkan defek lapang pandang relatif (skotoma) dan hilangnya ketajaman visual pada kasus dengan keterlibatan makula. Selanjutnya, neovaskularisasi pada iris di segmen anterior mata dapat berkembang menjadi sekuel segmen anterior iskemia. Pembuluh darah baru ini tumbuh ke arah sudut ruang anterior dan dapat menghalangi trabecular meshwork, sehingga meningkatkan resistensi aliran keluar dari aqueous humor. Hal ini menghasilkan peningkatan tekanan intraokular diikuti oleh atrofi optik (neovascular glaucoma) (Nentwich MM dan Ulbig MW, 2015).

\section{Angiogenesis pada Diabetes Retinopati}

Mekanisme yang mungkin terlibat dalam proses patogenesis DR antara lain, inflamasi, autofagia faktor pertumbuhan saraf dan epigenetik. Perubahan biokimia seperti stres oksidatif, aktivasi protein kinase $\mathrm{C}$ dan pembentukan produk akhir glikasi juga dapat dinilai sebagai respon retina terhadap hiperglikemia. Kinin B1 dan B2 diperkirakan meningkatkan permeabilitas pembuluh darah, infiltrasi leukosit dan peradangan. Terutama kinin B1, yang hampir tidak ada pada jaringan normal, diregulasi di retina pasien diabetes. Penelitian terbaru menunjukkan bahwa seluruh sistem neurovaskular retina terganggu oleh diabetes mellitus yang mengakibatkan hilangnya kontrol neurovaskular, neurodegenerasi dan neuroi-inflamasi, yang dapat dideteksi bahkan sebelum munculnya kerusakan vaskular. Secara klinis, berkurangnya kemampuan adaptasi terhadap gelap, gangguan penglihatan warna dan / atau kontras dan cacat bidang visual ditemukan selama pemeriksaan fungsional pasien diabetes. Retinopathy diabetik cenderung memburuk selama perubahan hormonal seperti masa remaja dan kehamilan (Nentwich MM dan Ulbig MW, 2015).

\section{Anti-angiogenesis dan Kayu Secang}

Kayu secang (Caesalpinia sappan L.) merupakan tanaman famili Caesalpiniaceae yang banyak ditemui di Indonesia. Kayu secang secara empiris diketahui memiliki banyak khasiat penyembuhan dan sering dikonsumsi oleh masyarakat sebagai minuman kesehatan (Sugiyanto 
RN, Putri SR, et al, 2013). Kayu secang diketahui memiliki manfaat kesehatan secara empiris dan mempunyai berbagai macam efek terapetik seperti antiinflamasi, analgesik, antiproliferatif, antivirus, immunomodulator, sitotoksik dan antikanker (Sugiyanto RN, Putri SR, et al, 2013; Zanin JLB, De Carvalho BA, et al, 2012). Air seduhan kayu secang dapat digunakan sebagai terapi pada beberapa penyakit seperti hipertensi, katarak, dismenorea, kanker, obesitas, dan penyakit vaskular seperti retinopati diabetikum (Nirmal NP, Rajput MS, et all, 2015).Adanya efek antikanker dan antiinflamasi pada kayu secang disebabkan karena adanya kandungan polifenol yang berfungsi sebagai antioksidan pada kayu secang, seperti flavonoid dan tannin (Gomes CBDS, Elisangela,et all, 2014). Senyawa flavonoid yang terkandung di dalam kayu secang adalah brazilin, sappanchalcone, dan brazilein (Hyun OK et al, 2007). Telah diketahui bahwa senyawa flavonoid dengan sifat antioksidannya memainkan peranan penting dalam antiangiogenesis. (Gomes CBDS, Elisangela,et all, 2014).

Kayu secang (Caesalpinea sappan) mengandung senyawa polifenol golongan flavonoid. Senyawa flavonoid inilah yang diduga berperan dalam kemampuan menghambat angiogenesis. Aksi penghambatan angiogenesis dari flavonoid dalam ekstrak metanolik kayu secang diduga melalui beberapa macam mekanisme. Hal ini berdasarkan pada penelitian penelitian terdahulu mengenai aksi flavonoid dalam menghambat angiogenesis. Pada penelitian terdahulu telah dibuktikan bahwa senyawa flavonoid, resveratrol dan quercetin mampu menghambat aspek-aspek angiogenesis (proliferasi, migrasi sel endotelial dan pembentukan pipa pembuluh darah). Proses angiogenesis diblok oleh inhibitor COX-2 yang diinduksi bFGF. COX2 berperan pada proses angiogenesis melalui sintesis prostaglandin (PG). Prostaglandin berperan penting di dalam induksi VEGF. Oleh karena itu penghambatan aktivitas COX-2 akan berakibat pada penghambatan angiogenesis. Selain itu, kandungan flavonoid dalam dalam Kayu secang (Caesalpinea sappan)berperan sebagai inhibitor angiogenesis melalui pengeblokan terhadap reseptor VEGF atau reseptor bFGF sehingga tidak dapat berikatan dengan faktor-faktor pertumbuhan tersebut atau menghambat matrix metalloproteinases (MMPs), enzim proteinase yang mengkatalisis rusaknya matriks ekstraselular, sehingga sel-sel endotelial mampu migrasi ke jaringan sekitarnya, membentuk pembuluh darah baru (Sugiarto IP, Nurulita NA, et all, 2010).

\section{SIMPULAN}

Diabetes retinopati merupakan salah satu komplikasi diabetes mellitus kronis yang dapat berikabat pada kebutaan. Diabetes retinopati terjadi sebagai akibat dari rangkaian proses inflamasi dan angiogenesis. Kayu secang diketahui mengandung senyawa polifenol golongan flavonoid yang dapat menghambat proses angiogenesis. Proses angiogenesis diblok oleh inhibitor COX-2 yang diinduksi bFGF. COX-2 berperan pada proses angiogenesis melalui sintesis prostaglandin (PG). Prostaglandin berperan penting di dalam induksi VEGF sehingga penghambatan aktivitas COX-2 akan berakibat pada penghambatan angiogenesis. Oleh karena itu, ekstrak kayu secang memiliki efek anti-angiogenesis yang dapat digunakan sebagai terapi adjuvant pada pasien diabetes retinopati.

\section{DAFTAR PUSTAKA}

Capitao M, Soares R, 2016,Angiogenesis and inflammation crosstalk in diabetic retinopathy Journal of Cellular Biochemistry Volume 117 April 2016, hal: 2443-2453.

Duh, Sun, et all, 2017, Diabetic retinopathy: current understanding, mechanisms, and treatment strategies, JCI Insight Volume 2 No. 14 Juli 2017, Hal: 1-13.

Gomes CBDS, Elisangela,et all, 2014, Evaluation of Antioxidant and Antiangiogenic Properties of Caesalpinia Echinata Extracts. Journal of Cancer Volume 5 No. 1, Hal: 143-150.

Hyun OK, et all, 2007, Use of the Extract of Caesalpinia Sappan L. and Compounds Therefrom, Seoul: Korea Institute of Science and Technology.

Kementrian Kesehatan RI, 2014, Situasi dan Analisis Diabetes Melitus, Pusat Data dan Informasi Kementrian Kesehatan Republik Indonesia, hal: 1-6.

Lathifah NL, 2017, Hubungan Durasi Penyakit Dan Kadar Gula Darah Dengan Keluhan Subyektif Penderita Diabetes Melitus Jurnal Berkala Epidemiologi, Volume 5 No. 2 Mei 2017, Hal: 231-238. 


\section{VOLUME 14 NOMOR 2 DESEMBER 2018}

Nentwich MM, Ulbig MW, 2015, Diabetic Retinopathy - Ocular Complications of Diabetes Mellitus, World Journal of Diabetes Volume 6 No 3 April 2015, hal: 489-499.

Nirmal NP, Rajput MS, et all, 2015, Brazilin from Caesalpinia sappan heartwood and its pharmacological activities: A review, Asian Pacific Journal of Tropical Medicine, Volume 8 No. 6, Hal: 421-430.

Olokoba AB, Obateru OA, 2012. Type 2 Diabetes Mellitus: A Review of Current Trends, Oman Medical Journal, Volume 27 No 4 Mei 2012, hal: 269-273.

Ramachandran $\underline{A}$, 2014, Know the signs and symptoms of diabetes, Indian J Med Res, Volume 140 No. 5 November 2014. Hal: 579-581.

Sugiarto IP, Nurulita NA, et all, 2010, Efek Antiangiogenesis Fraksi VI Dan VII Ekstrak Metanolik Kayu Secang (Cesalpinea Sappan L.). Jurnal Farmasi Indonesia (Pharmaceutical Journal of Indonesia), Volume 7 No. 2, Hal: 90-105.

Sugiyanto RN, Putri SR, et al, 2013, Aplikasi kayu secang (Caesalpinia sappan L.) dalam upaya prevensi kerusakan DNA akibat paparan zat potensial karsinogenik melalui MNPCE assay. Program Kreativitas Mahasiswa-Penelitian.

Zanin JLB, De Carvalho BA, et al, 2012, The genus Caesalpinia L.(Caesalpiniaceae): phytochemical and pharmacological characteristics. Molecules volume 17 No. 7. Hal: $7887-7902$. 